\title{
Çocuk İhmalini Ve İstismarını Önlemede Okul Çalışanlarının Sorumlulukları
}

\author{
Nilüfer KOÇTÜRK \\ SB Yıldırım Beyazıt Üniversitesi Yenimahalle Eğitim ve Araştırma Hastanesi \\ nilkeser@hacettepe.edu.tr
}

DOI: $10.21666 /$ muefd. 336170

\begin{abstract}
Özet
Sağllkl nesiller yetiştirmek öncelikle sağllkl çocuklarla mümkündür ve çocuğa kötü muamele de buna engel olan bir sorundur. Birçok araştırma bulgusu çocuk istismarına ve ihmaline maruz kalmanın çocuğu yaşam boyu etkilediğini ve ruhsal sorunlar, depresyon, travma sonrası stres bozukluğu, madde bağımlılığı, intihar girişimi ve özyaralama gibi tıbbi, psikolojik ve davranış bozukluklarına yol açtı̆ı̆ı göstermektedir. Eğitim hayatına devam eden çocukların gün içinde evlerinden daha çok okulda zaman geçirdikleri düşünüldügünde, çocuk istismarını ve ihmalini önleme ve müdahale çalışmalarında okullara büyük görevler düşmektedir. Ayrıca, okul ortamı çocuk istismarl ve ihmali için koruyucu bir faktör olabileceği gibi bir risk faktörü de olabilmektedir. Bu nedenle, bu çalışmada çocuk istismarını ve ihmalini önleme ve bu soruna müdahale konusunda okul ortamında yapılması gerekenler okul çalışanları (okul yöneticileri, ögretmenler ve okul psikolojik danışmanı) açısından ele alınmış ve ilgili alanyazın ışı̆̆ı̆da değerlendirilmişstir. Çalışmada önerilen eğitimsel ve yasal düzenlemelerin Türkiye'de çocuk koruma sistemini geliş̧tireceği, daha güvenli bir okul iklimini oluşturacağl ve risk altındaki çocuklara yönelik ĕ̌itim faaliyetlerinin etkinliğini artıracağı düşünülmektedir.

Anahtar Sözcükler: Çocuk istismarı, ihmal, önleme, okul yöneticisi, öğretmen, okul psikolojik danışmanı

\section{The Responsibilities of School Employees in Preventing Child Abuse and Neglect}

\begin{abstract}
Raising healthy generations is possible firstly through a healthy children and child maltreatment is an issue that prevents it. The weight of the evidence from the research suggests that exposure to child abuse and neglect can affect the lifetime of the child, and it can lead to medical, psychological and behavioral disorders including: mental health problems, depression, post-traumatic stress disorder, substance use disorders, suicidal behaviors and selfharm. Considering that children spend time even longer in school more than in the family, it behooves the schools to intervention studies in child abuse and neglect. Also, the school environment may be a protective factor and a risk factor for child abuse and neglect. Therefore, in this study the prevention and intervention of child abuse and neglect and what needs to be done in the school environment are discussed in terms of the employees of the school (school administrators, teachers and school counselor), and it has been evaluated in light of the relevant literature. It is believed that the proposed educational and legal regulations in this study will improve the effectiveness of educational activities for children at-risk, creating a safer school climate and improving the child protection system in Turkey.
\end{abstract}

Keywords: Child abuse, neglect, prevention, school administrator, teacher, school counselor

Çocuğa yönelik kötü muamele olarak da adlandırılan çocuk istismarı ve ihmali çocuğu yaşam boyu etkileyebilen, ruhsal olarak hem kısa hem de uzun dönemde bireyin ruh sağlığında depresyon, travma sonras1 stres bozukluğu gibi bozukluklara (De Bellis, Spratt ve Hooper, 2011; Fergusson, Boden ve Horwood, 2008) ve okul ve kariyer hayatında sorunlara (Daignault ve Hébert, 2008; Trickett, Noll ve Putnam, 2011) yol açabilen travmatik bir yaşantıdır. İhmal, ebeveyn veya çocuğun bakımından sorumlu kişilerin çocuğun temel gereksinimlerini karşılamaması iken istismar; çocuğa yönelik duygusal, cinsel ve/veya fiziksel içerikli olumsuz bir davranışla çocuğa zarar verme durumudur. Yapılan davranışın niteliğine veya çocukta yarattığı etkiye göre de çocuk istismarının, fiziksel, cinsel ve duygusal istismar olarak üç türü bulunmaktadır. Bu üç tür ayrı ayrı görülebileceği gibi çoğunlukla birarada görülebilmektedir. Söz gelimi, tecavüz mağduru bir çocuğun bu üç istismar türünü birarada yaşamış olması muhtemeldir. 
Her sorunda olduğu gibi çocuk istismarı ve ihmali ile baş etmenin en iyi yolu sorunun ortaya çıkmasını önlemektir. İstismarın önlenmesine yönelik çalıșmalar, hem istismara uğramamıș çocuk ve ergenlerin istismara maruz kalmalarının önlenmesi, hem de istismar mağduru çocukların tekrarlanan istismarlara uğramaması açısından son derece önemli ve tedaviyi de destekleyen bir yaklaşımdır (Aktepe, 2009). İstismarı önleme konusunda alanyazında sıklıkla üç aşamalı bir istismar önleme sürecinden bahsedilmektedir (Wurtele ve Kenny, 2010). Buna göre:

a. Birincil önleme amacı; istismar konusunda geniş çapta çocukları, ebeveynleri ve toplumu eğitmektir. Çocuklar için birincil önlemenin ana odağı, çocuğun çocuk istismarını tanımasını, istismarla başetmesini ve istismarı bildirmesini amaçlayan çocuk-merkezli, sınıf-merkezli programlardır.

b. İkincil önleme yöntemleri, yüksek risk altındaki bireylerdeki istismar potansiyelini artıran risk etmenlerinin azaltılmasını amaçlamaktadır. Söz gelimi, bu programlar madde kullanımı olan veya yüksek düzeyde riskli davranışlar sergileyen çocuklara uygulanmaktadır.

c. Üçüncül önleme yöntemi ise istismar gerçekleştikten sonra çocuğun tekrar istismara uğrama riskine yönelik yapılacak müdahaleleri içermektedir. Örneğin, alanyazında cinsel istismar mağdurlarının tekrarlanan cinsel istismar oranlarının yüksek olduğu bildirilmektedir (Kogan, 2005). Bu önleme türünde mağdur çocukların tedavisine odaklanılıp, tekrar istismara maruz kalmalarına yol açan psikososyal faktörlere müdahale edilmektedir.

Görüldüğü üzere, önleme aşamaları/süreçleri sadece istismar ve ihmal olayının öncesini kapsamamakta, olay sonrası yapılacak müdahaleleri de içermektedir. Yukarıda söz edilen önleme yöntemlerinin amaçları doğrultusunda, istismarı önleme programları toplum-tabanlı olabildiği gibi okul-tabanlı da gerçekleştirilebilmektedir (Crosson-Tower, 2003; Livny ve Katz, 2016; Wurtele, 2007; Wurtele, Moreno ve Kenny, 2008). Alanyazında özellikle okul ruh sağlığı hizmetlerinin önemi vurgulanmakta ve bu kapsamda okul tabanlı önleme; evrensel önleme, erken müdahale ve yoğun müdahale olarak üç boyutta ele alınmaktadır (Dwyer ve Van Buren, 2010). Evrensel önleme programı, bütün öğrencilerin sosyal, duygusal ve akademik işlevselliğini artırmaya yönelik programları ve stratejileri kapsarken; erken müdahale, ruh sağlığı ve akademik sorunlar yönünden bireysel ve çevresel riskleri bulunan öğrencilere yönelik stratejilerin uygulanmasını içermektedir (Akt., Dwyer ve Van Buren, 2010). Yoğun müdahalede ise duygusal ve davranışsal sorunları olan öğrencilere ruh sağlığı ve akademik hizmetler sunulmaktadir.

Öğrencilerin, gün içinde ebeveynlerinden bile daha uzun süre öğretmenleriyle zaman geçirdiği düşünüldüğünde, istismarı önleme çalışmalarında muhakkak okullar yer almalıdır (Page ve Page, 2011; Sanderson, 2004). Öğrencilerin okul psikolojik danışmanıyla ve öğretmenleriyle yakın ilişkilerinin olması, sorunlarını onlara anlatabiliyor olmaları ile okul psikolojik danışmanının ve öğretmenlerinin çocuklardaki davranış değişikliklerini fark edebilmeleri ve bildirim yapma zorunluluklarının olması gibi nedenler, çocuk istismarını belirlemede ve önlemede okul psikolojik danışmanlarının ve öğretmenlerin rollerinin ne kadar önemli olduğunu göstermektedir. Ayrıca, öğretmenlerin çocuklara ve ailelerine istismarı önleme konusunda eğitim verme imkânlarının bulunması çocukları korumada önemli bir firsattır (Crosson-Tower, 2003; Sanderson, 2004). Bir diğer yönden, okul ortamı da çocuk ihmali ve istismarı için bir risk faktörü olabilmekte, öğrenciler okul ortamında akranları tarafından zorbalığa maruz kalabildikleri gibi öğretmenleri tarafından da fiziksel, duygusal veya cinsel istismara maruz kalabilmektedirler (James v.d., 2008; Shumba, 2011). Bu nedenle, çocukları ihmal ve istismardan korumak için okullarda öncelikli olarak yapılması gereken okulun bir risk faktörü olmasını engellemektir. Bunun için öncelikle okulda güvenli sosyal çevre sağlanmalı; okul iklimi okul güvenliğini geliştirmeli, kazaları, şiddeti ve intiharı önlemelidir (Page ve Page, 2011). Güvenli sosyal ortamı yaratmak için de okul personeli çocuk istismarını ve ihmalini tolere etmemeli, disiplin yöntemleri yazılı olmalı, okul programları ve politikaları düzenli aralıklarla değerlendirilip olumlu okul ortamının yaratılması sağlanmalıdır.

Yukarıda görüldüğü üzere, çocuk istismarını ve ihmalini önlemede ve bu soruna müdahalede okullara büyük görevler düşmektedir. Ancak bu görevlerin yerine getirilmesi sadece okul psikolojik danışmanın bireysel çabasıyla mümkün olmayıp okul yönetiminin ve öğretmenlerin de sorumluluğundadır. $\mathrm{Bu}$ bağlamda, ilerleyen bölümde çocuk istismarını ve ihmalini önleme ve bu soruna müdahale konusunda okul ortamında yapılması gerekenler; okul yönetimi, öğretmen ve okul psikolojik danışmanı yönünden ele alınmıştır. 


\section{Çocuk İstismarını ve İhmalini Önlemede Okul Yönetiminin Sorumlulukları}

Çocuk istismarı ve ihmali konusunda okul yönetiminin tutum ve davranışları; gerek çocuğa kötü muameleyi önleme çalışmalarının gerçekleştirilmesinde gerekse mağdur öğrencilerin adli bildiriminin yapılmasında ve mağdura müdahale edilmesinde süreci kolaylaştırabileceği gibi zorlaştırabilir. Şöyle ki çocuk istismarının ve ihmalinin önemini kavramamış bir okul yönetimi, görevlerinin sadece çocuğun eğitim ihtiyaçlarını karşılaşmak olduğunu düşünerek ve ebeveynle ilişkisinin bozulmasında korkarak, eğitim ihmalinde bulunan bir ebeveynin ilgili kurum ve kuruluşlara bildirimini önemsemeyebilir. Bir diğer örnek olarak da okul yönetimi öğretmeni tarafindan cinsel istismara uğrayan bir öğrencinin adli bildirimini çocuğa inanmayarak, olayı hafife alarak, şüpheli öğretmeni korumak veya olayın içine girmemek için engelleyebilir (Grayson, 2006; Shakeshaft ve Cohan, 1995). Alanyazın incelendiğinde okul yönetiminin çocuk istismarı ve ihmali konusunda hem önleme hem de belirleme konusunda çeşitli sorumluluklarının olduğu belirtilmektedir (örn., Knoll, 2010; Mitchell, 2010; Roberts, 2005; Shannon, 2009). Bu bağlamda, okul yönetiminin sorumlulukları/görevleri şu şekilde sınıflandırılabilinir:

a. Eğitim ihmalini belirleme ve önleme: Okul yönetiminin en önemli görevleri arasındadır. Eğitim ihmali, çocuğun okula kayıt olmadığı, çocuğun okula aşırı devamsızlık yaptığı veya çocuğun özel eğitim hizmetlerinden yeterince yararlanamadığı durumlarda meydana gelmektedir (Legano, McHugh ve Palusci, 2009). Bir çocuk okula kayıt olmamışsa bunun sebebi öğrenilmeli, çocuğa ve ailesine eğitim danışmanlığı sağlanmalı ve gerekli durumlarda ilgili kurumlara bildirimde bulunulmalıdır. Aynı zamanda, okula kayıtlı öğrencilerin okul performansını, okula devam etmediği günleri değerlendirmeli, bu devamsızlıkların kaynağı öğrenilerek, bu konuda önlemler alınmalıdır. Örneğin, bir öğrenci ailesinin ekonomik durumu nedeniyle çalışıor olabileceği gibi, istismar veya aile-içi şiddet gibi nedenlerden ötürü de davranışsal sorunlar sergileyerek okul devamsızlığı yapıyor olabilir. Okul yönetimi bu ihtimalleri göz önünde tutarak gerekli değerlendirmeleri yapmalıdır.

b. Okul güvenliğinin sağlanmast: Okul yönetimi, okuda meydana gelebilecek çocuk istismarı ve ihmalini önlemek için güvenli bir okul ortamı yaratmalı ve okulda meydana gelebilecek kazalara yönelik güvenlik önlemleri almalıdır (Roberts, 2005). Buna ek olarak, engelli öğrencilerin eğitim haklarının ihlalini önlemek için onlara yönelik okulda fiziksel düzenlemeler yapılmalı, okuldaki mimari erişim sorunları ortadan kaldırılmalı ve okul yaşamları kolaylaştırılmalıdır (Akbulut, 2012). Söz gelimi, engelli rampalarının kot farklarının \%12'yi geçmeyecek şekilde düzenlenmesi, asansörü olmayan ve asansör yapılması uygun olmayan okullara bina içi kat merdivenlerine merdiven veya platform asansörlerinin yapılması okulda yapılacak fiziksel düzenlemelere örnek verilebilir (Dilbaz, 2016). Bir diğer yönden, öğrencilere yönelik bir anket çalışması ile zorbalık davranışı, kazalar gibi sorunlarla karşı karşıya kaldıkları okuldaki kör noktalar öğrenilebilinir (Shannon, 2009) ve bu noktalarda önlemler artırılabilinir. c. Çocuğa kötü muameleyi önleyen ve buna müdahale eden bir okul ikliminin oluşturulması: Fiziki önlemlerin yanı sıra, okul yönetimi istismarın açık bir şekilde konuşulabildiği, bu konuda sürekli alarmda (Mitchell, 2010) ve duyarlı olunduğu bir okul iklimi oluşturmalıdır. Söz gelimi, okulda hizmet veren öğretmenlerden kantin çalışanlarına ve servis şoförlerine kadar bütün okul personelinin çocuk istismarına ve ihmaline duyarlı bir tutum geliştirmelerini zorunlu kılmalıdır. Bunlara ek olarak, Dyregrov (2010) okulun kriz yönetimi konusunda hazırlıklı olması gerektiğini ve okulda istismar varlığı gibi travmatik bir olay olduğu zaman uygulanacak prosedürlerin hazırlanmasının okul yönetiminin sorumluluğunda olduğunu belirtmektedir. Akbulut (2012) ise engelli çocukların eğitim kalitelerinin ve verimlerinin artırılması amacıyla, engelli çocuklara yönelik tutum eğitimlerini içeren programlar oluşturulmasını ve öğretmenlerin bu programlara katılımının sağlanmasını önermektedir.

ç. Okul personelinin eğitimi: Çocuk istismarına ve ihmaline duyarlı bir okul ikliminin yaratılması için okul personelinin bu konuda eğitiminin sağlanması da okul yönetiminin sorumluluğundadır. Alanyazında okul yönetiminin bütün okul personelini önleme çalışmalarına dâhil etmesi gerektiği; şüpheli istismar durumlarında nasıl tepki gösterecekleri, nereden ve kimden yardım alacakları konusunda personele bilgilendirmeler yapılmasının ve eğitimlerin her yıl olmasının önemi vurgulanmaktadır (Barron ve Topping, 2010; Knoll, 2010; Mitchell, 2010). Page ve Page (2011) bu konudaki eğitimlerin çocuk gelişimi, çocuk istismarını belirleme ve bildirme, çocuğun bildirimde bulunması durumunda çocuk ile görüşme, aile dinamikleri, gizlilik, yasal ve etik sorunlar ile tedavi yaklaşımları konularından oluşmasını önermektedir. Bunların dışında, okul personeli aldıkları 
eğitimlerde öğretmen-öğrenci ilişkisinde hangi davranışların kabul edilebilir olduğu ve bu davranışlara dair açık kurallar konusunda eğitmelidir (Knoll, 2010; Shannon, 2009). Söz gelimi, öğreniciyle bedensel temas kurmama, öğrenciyi aşağılama-ad takma gibi davranışlar sergilememe bu kurallardan bazıları olabilir.

d. Adli bildirim yükümlülüğ̈̈: Okul yönetimi, ihmalden ve istismardan şüphelenildiği durumlarda mutlaka adli mercilere bildirimde bulunmalı ve bildirimde bulunan okul personelini desteklemelidir. Öğretmenler okul yönetiminden yeterli desteği göremediklerinde çocuk istismarını bildirmedikleri için mutlaka okul yönetimi öğretmenlere bu anlamda destek olmalıdır (Substance Abuse and Mental Health Services Administration, 2009). Türkiye'de 5237 sayılı Türk Ceza Kanununa göre de devlet memurlarının adli bildirim yükümlülügü bulunmaktadır (TCK, m. 279). Bu kanun maddesine göre okul yöneticileri gibi herhangi bir kamu görevlisi bir suçun işlendiğini yetkili makamlara bildirimde bulunmayı ihmal etmesi veya bu hususta gecikme göstermesi durumunda, altı aydan iki yıla kadar hapis cezası ile yargilanmaktadır.

e. Toplumsal duyarlılık yaratma: Okul yönetimi, personelinin eğitim almasını sağladı̆̆ı gibi öğrencilerini ve ebeveynlerini de istismarın belirtileri, öğretmen-öğrenci ilişkisinde hangi davranışların kabul edilebilir olduğu ve buna yönelik kurallar konusunda eğitmelidir (Knoll, 2010; Shannon, 2009). Ayrıca, okul yönetimi öğrencilere ve ailelere okul-tabanlı istismarı ve ihmali önleme programları uygulatmalı ve istismarın sıklı̆̆ını azaltmak konusunda her kesime yönelik önleyici çalışmalarda bulunmalidır (Shannon, 2009).

\section{Çocuk İstismarını ve İhmalini Önlemede Öğretmenlerin Sorumlulukları}

Çocuk istismarını ve ihmalini önlemede öğretmenlerin sorumlulukları incelendiğinde ise okul yönetiminin görevlerinde olduğu gibi hem önleme hem de müdahale aşamasında çeşitli sorumlulukları bulunmaktadır. İlgili alanyazın ışığında bu sorumluluklar aşağıda detaylı olarak sunulmuştur:

a. Çocuk istismarl ve ihmali konusunda bilinçlenme/eğitim alma: Gerek çocuğa uygulanan kötü muameleyi fark edebilmek gerekse çocuklara kötü muamelede bulunmamak için öğretmenlerin çocuk istismarının ve ihmalinin belirtilerini ve bu soruna hangi davranışların yol açtığını çok iyi düzeyde bilmeleri gerekmektedir. Söz gelimi, öğrenciye fiziksel görünümleriyle ilgili ad takmanın veya söz söylemenin öğrencide duygusal istismara yol açabileceğini bir öğretmenin bilmesi gerekmektedir. Buna yönelik olarak, bir araştırmada öğrencilerin öğretmenleri tarafından duygusal istismara uğrama oranının \%55.2'lere ulaştığı saptanmıştır (Ba-Saddik ve Hattab, 2012). Bir diğer yönden, ihmal ve istismar sonucunda çocuklarda görülebilen bazı belirtiler farklı şiddet düzeyinde sadece okul ortamında gözlenebilir ve öğretmenler aracılığıyla fark edilebilinir (Sanderson, 2004). Örneğin, okul başarısında ani düşüş, eve gitmeye isteksizlik veya okula çok erken gelme, kişisel güvenlik derslerinden sonra davranışlarda ani değişim olması, okula sıkça geç kalma veya okula devamsızlık sergileme, okulda belirli bir yere veya belirli bir kişi ile gitmede isteksiz olma, arkadaşlarını, öğretmenleri veya diğer yetişkinleri baştan çıkarıcı davranışlar sergileme, fiziksel eğitim derslerinde kıyafet değiştirmeye karşı isteksizlik veya bu derslerden kaçma ve evde sorunlar olduğuna yönelik imalarda bulunma bu belirtiler arasında sayılabilinir (Page ve Page, 2011). İhmalin olası göstergeleri olarak da çocuğun sıklıkla okul araç-gereçlerinin olmaması, yiyecek çalma veya yiyecekleri biriktirmesi, hava koşullarına uygun olarak giyinmemesi, çocuğun hijyeninin sürekli kötü olması, çocuğun devamsızlık yapması, okulda iken sürekli uyku halinde olması ve ders başarısında ani düşüş örnek verilebilir (Crosson-Tower, 2003). Ebeveynlerin ihmal ve istismar davranışlarına örnek olarak da çocuğun ders başarısı ile ilgilenmemeleri, veli toplantılarına gelmemeleri, çocuğu bir yük veya değersiz bir varlık olarak görmeleri, çocuk yaramazlık yaptığında fiziksel istismarda bulunması için öğretmene yetki vermeleri ve çocuğun muayenelerini yaptırmamaları sayılabilinir (Crosson-Tower, 2003).

Öğretmenlerin çocuk istismarı ve ihmali konusunda kendilerini geliştirmeleri hem mesleki hem de topluma karşı sorumluluklarıdır. Goldman ve Bradley (2011) üniversitelerin öğretmenlik bölümlerindeki öğretmen adaylarına çocuk istismarına yönelik uygulamalı eğitimlerin mezuniyet öncesinden verilmesi gerektiğini belirtmektedirler. Buna karşın, Türkiye'de öğretmenlerin çocuk istismarı ve ihmali konusunda lisans döneminde ders almaları zorunlu değildir. Bu eğitimsel eksikliğin giderilmesi de öğretmenlerin kendi çabalarına bağlıdır. Bu amaçla, öğretmenler çocuk istismarı ve ihmali konusunda çalışmalarda bulunan derneklerle işbirliği yapabilirler, hizmet-içi eğitim alabilirler ve ilgili alanyazını takip ederek bilgi düzeylerini geliştirebilirler. 
b. Önleme çalışmalarında bulunma: Çocuk istismarına yönelik önleme çalışmaları çocuğu, ebeveynleri ve toplumu hedeflemekte olup istismar konusunda farkındalığın arttırılmasını, olası istismar durumunda çocuğun kendini koruyabilmesini, kolayca bu durumu bir yetişkene bildirebilmesini ve böylece istismarıncının tekrar eden ve git gide artan bir şiddette çocuğu istismar etmesini engelleyebilmesini amaçlamaktadır (Crosson-Tower, 2003; Livny ve Katz, 2016; Wurtele, 2007; Wurtele v.d., 2008). Yurtdışı kaynaklı bazı önleme programları, öğrencilerin kendini korumaları konusunda eğitim almaları için öğretmenlerin seminer vermelerini veya müfredata konu eklemelerini içerirken, bazı programlar da bu konuda uzman olan kişilerin okula getirilmesini gerekli kılmaktadır (Page ve Page, 2011; Warden, 2005). Öğretmenler, müfredat konularını aksatmadan, verilen ders konularına adapte ederek de çocukların kötü muameleden korunmalarına yönelik eğitimler verebilirler. $\mathrm{Bu}$ amaçla, her yıl okul psikolojik danışmanından destek alarak rehberlik saatlerinde bu eğitimleri öğrencilere verebilir ve veli toplantılarında da çocuk istismarı ve ihmalinin önemi konusunda ebeveynleri bilinçlendirebilirler. Hem öğretmenlerin hem de okul psikolojik danışmanının koordineli olarak önleme eğitimlerinde bulunmaları da bu konuda okulda duyarlılık olduğuna dair öğrencilere ve ailelerine mesaj vereceği gibi verilen eğitimlerin pekişmesini de sağlayacaktır.

c. Okul ortamında istismarı önleme ve măgdur çocuğu fark edebilme/belirleme: Öğrenci sayısının yoğun olduğu sınıflarda veya okullarda ihmal ve istismar belirtilerinin fark edilmesinde en büyük görev sınıf öğretmenlerine düşmektedir. Öğrencinin mağduriyetini sakladığı ve öğretmenin de öğrencinin duygulanım ve davranış değişikliğini yeterince gözlemediği durumlarda ihmal ve istismar saptanamayacaktır. Bir diğer açıdan, öğrencinin bildirimde bulunması da öğretmeniyle yakın ilişkisine, ona olan güvenine bağlıdır. Kendisine yardım etmeyeceğini veya kendisini yargılayacağını düşünen bir öğrencinin öğretmenine bildirimde bulunması beklenmemelidir. Bazı öğretmenler de çocuğun duygu ve davranışlarını gözlem yapmanın veya çocuğa psikolojik açıdan destek olmanın görevleri arasında olmadığı, öğretmenin görevinin eğitim ve öğretim vermek olduğuna dair bir kanı bulunabilir. Ancak, şüphesiz güvenlik, bakım gibi temel ihtiyaçları karşılanmayan bir öğrenciye sadece ders anlatılması, verilecek eğitim hizmetinin kalitesini düşüreceği gibi, emeklerin de boşa gitmesine yol açacaktır.

Önceki araştırmalara göre, istismar eden kişi çocuğun okul arkadaşı olabileceği gibi okul çalışanı veya öğretmeni de olabilmektedir (Burgess, Welner ve Willis, 2010; Shakeshaft, 2003). Amerika' da 80.000 okuldaki öğrenciyle yapılan bir çalışmada 8.-11. sınıf öğrencilerinde öğretmenlerin cinsel istismarının oranı \%9.6 olarak saptanmış olup en çok sınıf öğretmenlerinin, ardından spor hocalarının, servis şöförlerinin ve yöneticilerin istismarda bulunabildiği belirlenmiş̧tir (Shakeshaft, 2003). Ancak, istismarcı öğretmenin cinsiyeti kadın veya erkek farketmeksizin, öğrenciler otorite figürü olmasından, aralarındaki güç farkından ve inanılmayacakları korkusundan öğretmenlerinin istismarını bildirmeyebilirler (Grayson, 2006; Knoll, 2010). Benzer şekilde, istismar şüphesi olan durumlarda öğretmenler de meslektaşları hakkında yanlış beyanda bulunmamak veya kendilerine dava açılabilir korkuysa olayı görmezden gelebilmektedirler (Grayson, 2006; Shakeshaft ve Cohan, 1995). Özellikle, olayın sıklığı, şiddeti, bildirim zorunluluğu gibi faktörler öğretmenlerin çocuk istismarı ve ihmalini bildirimlerini etkileyen faktörlerdir (Walsh, Bridgstock, Farrell, Rassafiani ve Schweitzer, 2008). Ancak öğretmenlerin istismarı durumunda da mağdur öğrencilerde okuldan kaçınma, düşük okul performansı sergileme gibi çeşitli şiddette ruh sağlığını etkiyebilen sorunlar görülmektedir (Grayson, 2006). Sanderson (2004) öğrencisini istismar eden öğretmenlerin belli bir öğrenciye ekstra özel ilgi gösterme, belli öğrencilere özel imtiyazlar verme ve özel öğretim zamanı ayırma, okulun diğer çalışanlarını bilgilendirmeden belli öğrencilerle gece konaklamalarını içeren okul dışı geziler ve seyahatler düzenleme, diğer akranlarından ve yetişkinlerden öğrenciyi uzaklaştırmaya ve manipüle etmeye çalışma gibi özellikler sergileyebileceklerini belirtmekte ve bu belirtiler açısından öğretmenleri meslektaşlarını gözlemlemesi konusunda uyarmaktadır. Bunlara ek olarak, Mitchell (2010) öğrencilerin fiziksel, duygusal ve davranışsal belirtilerinin izlenmesini, başka sorunlarda da görülebilmesine rağmen, belli bir derse girmek istemeyen veya öğretmenle iletişimde bulunmak istemeyen öğrencilerin olması durumında bu durumun nedenlerinin incelenmesi gerektiğini vurgulamaktadır. Özetle, alanyazında okul ortamındaki istismarı önlemek amacıyla öğretmenlerin, melektaşlarının öğrencilerle olan davranışlarını izlemesi, tarafsız davranması ve okul liderliği ile okul güvenliğinin sağlanması gibi çeşitli önerilerde bulunulmaktadır (Hobbs, 2007; Mitchell, 2010; Sanderson, 2004).

ç. Mă̆dur çocuğa doğru ve uygun yaklaşım sergileme: Öğretmenlerin çocuk istismarı ve ihmali konusunda bir diğer sorumlulukları ise; kendisine istismar bildiriminde bulunan bir öğrenciye uygun bir 
yaklaşım sergilemesidir. Çünkü öğretmenin sergileyeceği yanlış bir tutum çocukta ikincil travmaya yol açabilir. İkincil travma, yaşadığı istismar olayını bir yetişkine anlatan çocuğun ruh sağlığını etkileyen etmenlerden birisidir. Çoğu kez daha ilk travmanın etkileri atlatılmadan oluşan ikincil travma, insanların başlarına gelen felakatlerden sorumlu tutulmaları ya da kendi kendilerini sorumlu tutmalarıdır (Sungur, 1999). Bu nedenle, bir öğrencinin istismara maruz kaldığını öğreniyor olmak öğretmen veya okul yönetimi için zor bir durum olsa da öğrenciye uygun tepki vermek ikincil travmaların önlenmesi açısından oldukça önemlidir. Mağdur çocuğa uygun yaklaşım sergilerken de yaşadığı olaydan dolayı öğrenci suçlanmamalı, acıma, kızma, suçlama, olayı hafife alma gibi duygular, davranışlar ve aşırı tepkileri sergilemekten kaçınılmalıdır. Söz gelimi, cinsel istismar mağduru bir çocuğun anlattıklarını dinlerken fiziksel temasta bulunulmamalıdır.

d. Adli bildirimde bulunma: Öğretmenlerin ihmali ve istismarı bildirmede yasal yükümlülükleri bulunmaktadır. Birleşmiş Milletler Çocuk Hakları Sözleşmesi'nin 34. Maddesi’ne paralel hükümler içeren 5237 sayılı Türk Ceza Kanunu'nun 103. maddesinde çocukların cinsel istismarı suç olarak düzenlenmiştir. Öğretmenlerin, cinsel istismar şüphesinin olduğu durumlarda dahi bildirimde bulunması yasal bir yükümlülük olup bu yükümlülüğün yerine getirilmemesi sonucunda iki yıla kadar hapis cezası ile yargılanmaktadırlar (TCK. 279. m). Buna karşın, bazı durumlarda öğretmenler bildirim yapma konusunda isteksiz olabilmektedirler. $\mathrm{Bu}$ gönülsüzlügün nedenlerine yönelik olarak da alanyazında şunlar belirtilmektedir (Crosson-Tower, 2003; Page ve Page, 2011):

- $\quad$ Çocuk istismarını belirleme ve bildirme konusunda yetersiz bilgi düzeyi

- $\quad$ Olayin içerisinde yer alma korkusu

- $\quad$ Okul yönetiminin öğretmenleri desteklememesi

- $\quad$ Aile ilişkilerine ve ana-babalık uygulamalarına müdahale ediyor olma konusunda endişelenme

- $\quad$ Ebeveynlerin birbirlerinden olası öç alma davranışları konusunda kaygılanma

- $\quad$ Ailelerin okula yabancilaşması konusunda kaygılanma

- Daha önceki istismar bildiriminde yaşanan olumsuzluklar (örn., yargıya güvensizlik duyma) olabilmektedir.

Yukarıda belirtilen nedenler ne kadar güç olursa olsun, çocuk koruma sisteminin iyi işlemesi adına öğretmenler bildirime yönelik olumlu bir tutum sergilemelidirler. Öğretmenlerin adli mercilere istismar bildiriminde bulunması, istismara müdahale etmeyi, istismarın kısa ve uzun dönem etkilerini sınırlamayı ve istismarın devam etmemesini/tekrarlanmamasını sağlayacaktır (Walsh, Rassafiani, Mathews, Farrell ve Butler, 2010).

e. Okul rehberlik servisi ile işbirliği sergileme: Daha önce belirtildiği üzere, ihmale ve istismara maruz kalmış çocuğu fark edebilme, çocuğun mağduriyetini bildirmesi durumunda da uygun yaklaşım sergileme ve adli bildirimde bulunma konusunda öğretmenlerin sorumlulukları bulunmaktadır. Adli bildirim sonrası ise mağduriyetin çocuk üzerindeki etkisinin belirlenmesi ve terapötik müdahalelerde bulunulması için öğrencinin psikolojik destek alması gerekmektedir. Tüm bu süreçte öğretmenlerin ve rehberlik servisinin uyum ve kordinasyon içerisinde çalışmasıyla istismarın ve ihmalin öğrencinin eğitim ve sosyal yaşamında yarattığ 1 olumsuz etkinin azaltılması ve yok edilmesi sağlanmalıdır. Örneğin, istismar ve ihmal sonrası öğrencinin olumsuz etkilenen benlik algısının yükseltilmesi için ortak çalışmalarda bulunulabilir, etiketlenmenin önlenmesi sağlanabilir ve sınıf öğretmeni öğrencinin küçük başarılarında bile kendisini onure edici geri bildirimde bulunarak mağdurun kendisini başarılı hissetmesine olanak tanıyabilir.

Sonuç olarak, öğretmenlerin çocuk istismarı ve ihmali konusunda çeşitli sorumlulukları bulunmakta olup bu sorumluluklar; bilinçlenme/eğitim alma, önleme çalışmalarında bulunma, okul ortamında istismarı önleme ve mağdur öğrenciyi fark edebilme/belirleme, mağdura uygun yaklaşım sergileme, adli bildirimde bulunma ve okul rehberlik servisi ile işbirliği sergileme olarak sıralanabilir. Bu görevlerden mağdur çocuğa uygun yaklaşım sergilememe ile adli bildirimde bulunmama yasal olarak suç teşkil etmektedir. Bu davranışların sergilenmesi durumunda öğretmenler ve okul yönetimi; görevi ihmal, görevi kötüye kullanma ve adli bildirim yükümlülüğ̈̈nü yerine getirmeme suçlarından yargilanabilmektedirler.

\section{Çocuk İstismarını ve İhmalini Önlemede Okul Psikolojik Danışmanlarının Sorumlulukları}


Çocuk istismarını ve ihmalini önlemede öğretmenler için belirtilen bütün sorumluluklar okul psikolojik danışmanları için de geçerlidir. Bunlara ek olarak, okul psikolojik danışmanlarının çocuğun ruh sağlığının korunması açısından başka sorumlulukları da bulunmaktadır. Bu sorumlulukların başında çocukların istismara uğramaması için tüm öğrencilere, ailelere ve diğer okul çalışanlarına önleyici faaliyetlerde bulunmak, istismara ve ihmale maruz kalma riski yüksek olan çocukları izlemek (Page ve Page, 2011), onlara özgü önleyici faaliyetlerde bulunmak ve ilgili sosyal destek mekanizmaları ile bağlantı kurarak bireysel ve ailesel risk faktörlerini azaltmaktır. Bir öğrencinin istismara uğrama durumunda ise sorumlulukları krize müdahale etmek ve okulda yaşanması muhtemel olumsuz olayları (örn., intihar, etiketlenme) önlemek, çocukta oluşabilecek ikincil travma maruziyetinin önlenmesini ve eğitimsel ve ruhsal yönden olaydan en az etkilenmesini sağlamaktır. Öğrencinin olaydan en az etkilenmesi için de yapması gerekenler; çocuğun terapötik destek ihtiyacını belirlemek, eğitimi doğrultusunda terapötik müdahalede bulunmak ve psikiyatrik destek alan çocuklarda hastane-okul işbirliğini kurmaktır.

Daha önce vurgulandığı üzere, olayın ortaya çıkış şekline bağlı olarak bildirim sonrası okulda bazı olumsuz olayları yaşanabilir. Bu olumsuz olaylar okul personeli veya çocuğun arkadaşları tarafindan etiketleme veya damgalama olabileceği gibi, aile ile de yaşanması muhtemeldir. Söz gelimi, ensest mağduru olan bir öğrencinin istismar bildiriminde bulunmasının ardından, ebeveyne istismar bildiriminin okulda yapılması durumunda ebeveyn okul ortamında bir olay çıkartabilir ve bu durum diğer öğrenciler için travmatik olabileceği gibi mağdur öğrencinin de okul ortamında etiketlenmesine veya intihar girişimine yol açabilir. Çocuğun hayatını tehlikeye atabileceği, ana-babanın çocuğu/yetkilileri istismar bildiriminden vazgeçirmeye çalışabileceği, çocuğu kaçırabileceği veya okuldan alabileceği, ensest vakalarda hem mağdurun hem de istismarcının intihar etme riskini artırabileceği için aile görüşmesinin bu konuda eğitim almış, adli mercilerdeki kişilere bırakılması daha yararlı olabilir (Crosson-Tower, 2003).

Okul psikolojik danışmanlarının sorumluluklarından biri olan çocuk istismarını ve ihmalini önleme amaciyla da çocuklara, ebeveynlere, okul personeline ve mümkün olduğu durumlarda da topluma her y1l bu konuda eğitimler düzenlenmesi yararlı olacaktır (Cox, Webber ve Joachim, 2007; Mitchell, 2010; Sanderson, 2004; Warden, 2005). Alanyazında, çocukların kendilerini koruma becerilerini edinmeleri amacıyla "Vücut Güvenliği Eğitim Programı" (Wurtele, 2007), Kırmızı Bayrak/Yeşil Bayrak (Kolko, Moser, Litz ve Hughes, 1987), "Güvenli Kal” (MacIntyre ve Carr, 1999) gibi çeşitli önleme programlarının kullanıldığı görülmekte olup özellikle çocuk odaklı önleme programlarının çocukların, istismar olan ve olmayan durumları ayırabilmesini, bilgi düzeylerini artırmasını, kişisel güvenlik becerilerini ilerletmesini ve ikincil kazanç olarak da çocukların istismarı bildirmelerini sağlayabildiği vurgulanmaktadır (Topping ve Barron, 2009; Wurtele, 2009). Amerika'da bir araştırmada çocukların 2/3'ünün okul tabanlı önleme programlarına katıldığı belirlenmiştir (Akt., Finkelhor, 2007). Ancak, ülkemizdeki okulöncesi ile ilk ve orta öğretim okullarında öğrencilere ve ebeveynlerine standart olarak ihmali ve istismarı önleme programı uygulanmamaktadır. Milli Eğitim Bakanlığı bünyesinde, kanıta dayalı, kültüre duyarlı ve uygulayıcı yönergesi bulunan bir önleme programının hazırlanması ve tüm okullarda kullanımının sağlanması Uluslararası Çocuk Haklarına Dair Sözleşmede vurgulanan "çocuğun yüksek yararı" ilkesinin sağlanması açısından çok önemlidir.

Okul psikolojik danışmanlarının çocuk ihmalini ve istismarını önlemek amacıyla okul ortamında hazırladıkları eğitimlere ebeveynleri de dahil etmesi verilen eğitimlerin etkililiğini artırabileceği gibi bilgisizlikten kaynaklanan ebeveyn davranışlarının değiştirilmesinde de yararlı olacaktır (Plummer, 2006; Wurtele ve Kenny, 2010). Ebeveynlerle yapılan araştırmalar, ebeveynlerin istismar ve ihmal konusunda bilgi eksikliklerinin bulunduğunu ve çeşitli mitlere sahip olduklarını göstermektedir (Keser, Odabaş ve Elibüyük, 2010; Bilge, Taşar, Kılınçoğlu, Özmen ve Tıraş, 2013). Yurtdışında ebeveynlere yönelik "Güvenli Çocuk Ebeveynliği" (Wurtele v.d., 2008) gibi çeşitli eğitim programları bulunmakta ve bu programların bir kısmının özellikle risk altındaki ailelere ve adölesan annelere yönelik düzenlendiği görülmektedir (Akt., Crosson-Tower, 2003).

Son olarak, okul psikolojik danışmanlarının çocuk istismarı ve ihmali konusunda toplumun bilinçlendirilmesinde de aktif görev alması çok önemlidir. Ülkemizde çocuk istismarı ve ihmali konusunda çalışmalarda bulunan "Çocuk İstismarını ve İhmalini Önleme Derneği”" ve "Çocuk ve Bilgi Güvenliği Derneği” ile "Çocuğa Karşı Şiddeti Önlemek için Ortaklık A ̆̆̆”" ve "Çocuklara Yönelik Ticari Cinsel Sömürü ile Mücadele Ağı” gibi çeşitli dernekler ve ağlar bulunmaktadır. Okul psikolojik 
danışmanları bu derneklerde ve ağlarda aktif görev almalı, önleme programlarının hazırlanmasına yardım etmeli ve gerektiği durumlarda da uzman desteğinden yararlanmalıdır. Bunlara ek olarak, toplumun bilinçlendirilmesi, problemin varlığından haberdar olması, problemle ilgili bilginin arttırılması, konu ile ilgili tutum ve davranışların değişmesi için medyadan yararlanılmalı, yazılı ve görsel basında konuya ayrıntılı olarak yer verilmesini sağlamak için çalışmalarda bulunulmalıdır (Crosson-Tower, 2003).

\section{Sonuç}

Sonuç olarak, okul yöneticileri, öğretmenler ve okul psikolojik danışmanları çocuğa yönelik kötü muameleyi hem önlemede ve belirlemede hem de bu soruna müdahale etmede kritik öneme sahiptirler. Türkiye, Çocuk Haklarına Dair Sözleşmeyi imzalamış bir ülke olarak çocukların kötü muameleden korunması gerektiğini ve bu konuda çalışmalarda bulunacağını uluslararası düzeyde kabul etmektedir. Ancak bu doğrultuda, ülkemizde eğitimcilerin çocuk istismarını ve ihmalini önlemede rollerine dair eğitimsel ve yasal düzenlemeler bulunmamaktadır. Çocuk istismarı ve ihmali konusunda herhangi bir eğitim almadan mezun olan bir öğretmen adli bildirim yükümlülüğünü yerine getirmediği için yasal bir sorunla karşılaştığında olayın önemini kavrayabilmektedir. Bu nedenle, bütün eğitim fakültelerinde lisans düzeyinde "çocuk istismarı ve ihmali" adıyla zorunlu bir dersin olması çocuk istismarını ve ihmalini önlemedeki ihtiyaçlardan biridir. Bir diğeri ise çocuğa yönelik kötü muameleyi önlemede okul yöneticilerinin, öğretmenlerin ve okul psikolojik danışmanlarının rollerinin ve bu sorunla karşılaştıklarında yapılması gerekenlerin açıkça belirtildiği bir yasal düzenleme gerekmektedir. Son olarak, Milli Eğitim Bakanlı̆̆ı'nın ve yöneticilerinin desteği ile bütün okul öncesi, ilköğretim ve ortaöğretim dönemindeki çocuklara ve ebeveynlere yönelik zorunlu önleme programlarının hazırlanması ve uygulanması oldukça önemlidir. Söz edilen bu eğitimsel ve yasal düzenlemelerin Türkiye'de çocuk koruma sistemini geliştireceği, daha güvenli bir okul iklimini oluşturacağ 1 ve risk altındaki çocuklara yönelik eğitim faaliyetlerinin etkinliğini artıracağı düşünülmektedir.

\section{Kaynakça}

Akbulut, S. (2012). Gerçekten eşit miyiz? Acı (ma), zayıf gör (me) ve yok say (ma) ekseninde engelli ayrımcılığı. K. Çayır ve M.A. Ceyhan (Eds.), Ayrımcılık: Çok boyutlu yaklaşımlar, içinde.İstanbul: İstanbul Bilgi Üniversitesi Yayınları.

Aktepe, E. (2009). Çocukluk çağı cinsel istismarı. Psikiyatride Güncel Yaklaşımlar, 1(2), 95-119.

Barron, I., \& Topping, K. (2010). School-based child sexual abuse prevention programs: Implications for practitioners. American Professional Society on the Abuse of Children (APSAC) Advisor, 22(2\&3), 11-19. DOI:10.3102/0034654308325582

Ba-Saddik, A.S., \& Hattab, A.S. (2012). Emotional abuse towards children by schoolteachers in Aden Governorate, Yemen: A cross-sectional study. BMC Public Health, 12(1), 647-654. DOI:10.1186/1471-2458-12-647

Bilge, Y.D., Taşar, M.A., Kılınçoğlu, B., Özmen, S., \& Tıraş, Ü. (2013). Alt sosyoekonomik düzeye sahip anne-babaların çocuk istismarı ve ihmali hakkındaki bilgi düzeyleri, deneyimleri ve kullandıkları disiplin yöntemleri. Anadolu Psikiyatri Dergisi, 14(1), 27-35. DOI:10.5455/apd.35949

Burgess, A.W., Welner, M., \& Willis, D.G. (2010). Educator sexual abuse: Two case reports. Journal of Child Sexual Abuse, 19(4), 387-402. DOI:10.1080/10538712.2010.495045

Cox, J.M., Webber, B., \& Joachim, G. (2007). A community program to fight child abuse: The Fort Wayne Children's Foundation and Kids' Law. Journal of Manipulative and Physiological Therapeutics, 30(8), 607-613. DOI:10.1016/j.jmpt.2007.08.001

Crosson-Tower, C. (2003). The role of educators in preventing and responding to child abuse and neglect. Fairfax, VA: Caliber Associates.

Daignault, I.V., \& Hébert, M. (2008). Short-term correlates of child sexual abuse: An exploratory study predicting girls' academic, cognitive, and social functioning 1 year later. Journal of Child \& Adolescent Trauma, 1(4), 301-316. DOI:10.1080/19361520802505693

De Bellis, M.D., Spratt, E.G., \& Hooper, S.R. (2011). Neurodevelopmental biology associated with childhood sexual abuse. Journal of Child Sexual Abuse, 20(5), 548-587. DOI:10.1080/10538712.2011.607753 
Dilbaz, A.U. (2016). Temel eğitim okullarında bedensel engelli öğrenciler için yapılması gereken fiziki düzenlemeler. (Tezsiz yüksek lisans proje önerisi). Pamukkale Üniversitesi Eğitim Bilimleri Enstitüsü. Denizli. http://acikerisim.pau.edu.tr/xmlui/handle/11499/1023 adresinden 01.07.2017 tarihinde alınmıștır.

Dwyer, K., \& Van Buren, E. (2010). School mental health: Prevention at all levels. B. Doll, W. Pfohl ve J. Yoon (Eds.), Handbook of youth prevention science içinde, (s. 45-69), NY: Routledge.

Dyregrov, A. (2010). Supporting traumatized children and teenagers: A guide to providing understanding and help. UK: Jessica Kingsley Publishers.

Fergusson, D.M., Boden, J.M., \& Horwood, L.J. (2008). Exposure to childhood sexual and physical abuse and adjustment in early adulthood. Child Abuse \& Neglect, 32(6), 607-619. DOI:10.1016/j.chiabu.2006.12.018

Finkelhor, D. (2007). Prevention of sexual abuse through educational programs directed toward children. Pediatrics, 120(3), 640-645. DOI:10.1542/peds.2007-0754

Goldman, J.D.G., \& Bradley, G.L. (2011). Assessing primary school student-teachers' pedagogic implementations in child sexual abuse protection education. European Journal of Psychology of Education, 26(4), 479-493. DOI:10.1007/s10212-011-0059-4

Grayson, J. (2006). Sexual abuse by educators and school staff. Virginia Child Protection Newsletter, $76,1-6$.

Hobbs, C. (2007). Child sexual abuse: The problem. S. R. Meadow, J. Mok ve D. Rosenberg (Eds.), $A B C$ of child abuse içinde, (4. Baskı), UK: Blackwell Publishing Ltd.

James, D.J., Lawlor, M., Courtney, P., Flynn, A., Henry, B., \& Murphy, N. (2008). Bullying behaviour in secondary schools: What roles do teachers play? Child Abuse Review, 17(3), 160-173. DOI:10.1002/car.1025

Keser, N., Odabaş, E., \& Elibüyük, S. (2010). Ana-babaların çocuk istismarı ve ihmali konusundaki bilgi düzeylerinin incelenmesi. Türkiye Çocuk Hastalıkları Dergisi, 4(3), 150-157.

Knoll, J. (2010). Teacher sexual misconduct: Grooming patterns and female offenders. Journal of Child Sexual Abuse, 19(4), 371-386. DOI:10.1080/10538712.2010.495047

Kogan, S.M. (2005). The role of disclosing child sexual abuse on adolescent adjustment and revictimization. Journal of Child Sexual Abuse, 14(2), 25-47. DOI:10.1300/J070v14n02 02

Kolko, D., Moser, J., Litz, J., \& Hughes, J. (1987). Promoting awareness and prevention of childsexual victimization using the Red Flag/Green Flag Program: An evaluation withfollow-up. Journal of Family Violence, 2(1), 11-35.

Legano, L., McHugh, M.T., \& Palusci, V.J. (2009). Child abuse and neglect. Current Problems in Pediatric and Adolescent Health Care, 39(2), 1-26. DOI:10.1016/j.cppeds.2008.11.001

Livny, K.A., \& Katz, C. (2016). Schools, families, and the prevention of child maltreatment: Lessons that can be learned from a literature review. Trauma, Violence, \& Abuse, DOI:10.1177/1524838016650186

MacIntyre, D., \& Carr, A. (1999). Evaluation of the effectiveness of the Stay Safe Primary Prevention Programme for child sexual abuse. Child Abuse \& Neglect, 23(12), 1307-1325. DOI:10.1016/S0145-2134(99)00092-7

Mitchell, M.W. (2010). Child sexual abuse: A school leadership issue. The Clearing House: A Journal of Educational Strategies, Issues and Ideas, 83(3), 101-104.DOI:10.1080/00098651003655936

Page, R.M., \& Page, T.S. (2011). Promoting health and emotional well-being in your classroom. (5. Bask1). USA: Jones and Bartlett Publishers.

Plummer, C.A. (2006). The discovery process: What mothers see and do in gaining awareness of the sexual abuse of their children. Child Abuse \& Neglect, 30(11), 1227-1237. DOI:10.1016/j.chiabu.2006.05.007

Roberts, H. (2005). Intervening to prevent accidents. B. Gillham ve J.A. Thomson (Eds.), Child safety: Problem and prevention from preschool to adolescence: A handbook for professionals içinde, (s. 53-64). London: Routledge.

Sanderson, C. (2004). The seduction of children: Empowering parents and teachers to protect children from child sexual abuse. UK: Jessica Kingsley Publishers. 
Shakeshaft, C. (2003). Educator sexual abuse. Hofstra Horizons, 10-13. https://www.hofstra.edu/pdf/about/administration/provost/hofhrz/hofhrz_s03_shakeshaft.pdf adresinden 30.07.2017 tarihinde alınmıştır.

Shakeshaft, C., \& Cohan, A. (1995). Sexual abuse of students by school personnel. Phi Delta Kappan, 76(7), 513-520.

Shannon, J.B. (2009). Child abuse sourcebook. (2. Bask1). Omnigraphics, Inc.

Shumba, A. (2011). Student teachers' perceptions of the nature, extent and causes of child abuse by teachers in Zimbabwean secondary schools. Journal of Social Sciences, 28(3), 169-179.

Substance Abuse and Mental Health Services Administration. (2009). Child sexual abuse fact sheet. U.S. Department of Health and Human Services (HHS). http://www.nctsnet.org/nccts/asset.do?id = 1216 adresinden 30.06.2017 tarihinde alınmıştır.

Sungur, M.Z. (1999). İkincil travma ve sosyal destek. Klinik Psikiyatri, 2, 105-108.

Topping, K., \& Barron, I. (2009). School-based child sexual abuse prevention programs: A review of effectiveness. Review of Educational Research, 79(1), 431-463. DOI:10.3102/0034654308325582

Trickett, P.K., Noll, J.G., \& Putnam, F.W. (2011). The impact of sexual abuse on female development: Lessons from a multigenerational, longitudinal research study. Development and Psychopathology, 23(2), 453-476. DOI:10.1017/S0954579411000174

Walsh, K., Bridgstock, R., Farrell, A., Rassafiani, M., \& Schweitzer, R. (2008). Case, teacher and school characteristics influencing teachers' detection and reporting of child physical abuse and neglect: Results from an Australian survey. Child Abuse \& Neglect, 32(10), 983-993. DOI:10.1016/j.chiabu.2008.03.002

Walsh, K., Rassafiani, M., Mathews, B., Farrell, A., \& Butler, D. (2010). Teachers' attitudes towardreporting child sexual abuse: Problems with existing research leading to new scaledevelopment. Journal of Child Sexual Abuse, 19(3), 310-336. DOI:10.1080/10538711003781392

Warden, D. (2005). The prevention of child sexual abuse. B. Gillham ve J.A. Thomson (Eds.), Child safety: Problem and prevention from preschool to adolescence: A handbook for professionals içinde, (s. 122-133). London: Routledge.

Wurtele, S.K. (2007). Body safety training workbook. www.sandywurtele.com adresinden 01.07.2017 tarihinde alınmıştır.

Wurtele, S.K. (2009). Preventing sexual abuse of children in the twenty-first century: preparing for challenges and opportunities. Journal of Child Sexual Abuse, 18(1), 1-18. DOI:10.1080/10538710802584650

Wurtele, S.K., \& Kenny, M.C. (2010). Partnering with parents to prevent childhood sexual abuse. Child Abuse Review, 19(2), 130-152. DOI:10.1002/car.1112

Wurtele, S.K., Moreno, T., \& Kenny, M. (2008). Evaluation of a sexual abuse prevention workshop for parents of young children. Journal of Child \& Adolescent Trauma, 1(4), 331-340. DOI:10.1080/19361520802505768 